\title{
REVISITING A CULTURE OF TOLERANCE RELATING TO RELIGIOUS UNFAIR DISCRIMINATION IN SOUTH AFRICA (PART 1) ${ }^{1}$
}

\author{
Radley Henrico \\ BProc LLB LLM LLD \\ Senior Lecturer, Public and Procedural Law \\ University of Johannesburg \\ Advocate of the High Court of South Africa
}

\section{SUMMARY}

On account of its nature and scope, this article has been divided into two parts. The aim of this work is to explore religious unfair discrimination in South Africa in the context of the imperative of the need to tolerate differences. In Part 1, the importance of tolerance of differences in a secular multicultural society will be discussed. When the expression of religious freedom in the workplace or in greater society conflicts with other fundamental rights, the balancing of these conflicting rights is never a simple exercise. Whilst the adjudication of such conflicting rights may call for the imperatives of rationality, reasonableness, and proportionality to be applied, such conflict cannot only be conceived of in terms of the lens of adjudication. The need to live in a multicultural, secular society overflowing with divergent interests demands a culture of accommodation. This article further examines the fact that whether tolerance is conceived of as "thin" or "thick" tolerance, it is essentially concerned with a situation of forbearance and is not celebratory. In the spirit of commitment to true democratic transformation, it is argued that the need to celebrate differences is more imperative than merely tolerating differences.

1

\section{INTRODUCTION}

The Bill of Rights contained in the Constitution of the Republic of South Africa, $1996^{2}$ guarantees a number of fundamental human rights and freedoms. None of them is absolute - they are all subject to specific or general limitations. Moreover, these fundamental rights and freedoms often compete due to a clash of interests; for example, an expression of religious freedom in the workplace may be at in conflict odds with the inherent

This article draws on the unpublished LLD thesis by the author titled "Religious Discrimination in the South African Workplace" (Northwest University Potchefstroom 2017).

2 Hereinafter "the Constitution". 
requirements of the job ${ }^{3}$. This conflict is exacerbated by the inherent imbalance of power characteristic of most typical employment relationships. The adjudication of such conflicting rights often results in one right being limited in favour of advancing the competing rights. Making this determination is never a simple exercise. This is on account of the fact that it calls for a value-based judgment premised on notions of rationality, reasonableness and proportionality.

In the context of the employment relationship, it is not always desirable for parties to resort to adjudication, in the sense of compulsory arbitration ${ }^{4}$ or formal litigation. ${ }^{5}$ This is simply due to the fact that either instance is usually indicative of the fact that the relationship of trust between the parties has broken down irretrievably.

The aim of this paper is to reflect on the role played by tolerance in religious unfair discrimination in South Africa. The rationale for doing so is to attempt to obtain a better understanding of the meaning of tolerance as it relates to religious unfair discrimination. The purpose of doing so is firstly to understand what is meant by tolerance in the context of religious unfair discrimination in South Africa; secondly, determining whether in the context of the South African constitutional dispensation, tolerance is in fact sufficiently suitable and appropriate in addressing religious unfair discrimination. This question is posed against the overarching concern that true commitment to a constitutional democratic order should extend beyond mere tolerance to the actual celebration of religious freedoms.

\section{TOLERANCE IN RELATION TO RELIGIOUS UNFAIR DISCRIMINATION IN SOUTH AFRICA}

\section{Freedom of religion in a secular society}

The right to freedom of religion in South Africa is expressly protected under section 15(1) of the Constitution. It is not a stand-alone right, as is the case, for example, with the right to life. ${ }^{6}$ Expressed alongside other rights, namely freedom of "conscience", "thought", "belief" and "opinion", it has given rise to extensive debate as to the precise meaning of the term "religion". Religion cannot be confined to a universal definition. ${ }^{9}$ This view appears notionally to have been influenced by broad latitudinous interpretations placed on notions such as "conscience", "thought", "belief", "opinion" and even "culture" by various decisions of the Constitutional Court. ${ }^{8}$ As a result, the notion of

\footnotetext{
Hereinafter "IROJ".

4 Before a bargaining council having jurisdiction, or before the Commission for Conciliation, Mediation and Arbitration.

By means of Notice of Motion or Trial Action.

$\mathrm{S} 11$ of the Constitution.

This analysis draws on the following article by the author, Henrico "Understanding the Concept of 'Religion' within the Constitutional Guarantee of Religious Freedom" 2015 TSAR 784.

8 See $S$ v Lawrence, $S$ v Negal; $S$ v Solberg 1997 (4) SA 1176 (CC) par 92; Christian Education South Africa v Minister of Education 2000 (4) SA 757 (CC) par 33; Prince $v$
} 
"religion" cannot be confined to a mere subjectively and personally ${ }^{9}$ held "faith and belief" - however bizarre such belief may appear to be to others. ${ }^{10}$ It is sufficiently broad to constitute a "part of a way of life, of a people's temper and culture". ${ }^{11}$ A notional difference between religion and culture is that the former is ordinarily associated with individual belief whereas the latter reflect traditions or beliefs of the community.

Given the variety of religions in South Africa ${ }^{13}$ and the fact that religious freedom is protected, the question remains to what extent it can be said that South Africa is a secular society, as opposed to a religious society. Alternatively, would it be more accurate to refer to South Africa as a neutral society taking into account the role played by the government with reference to religious freedoms? It would be no exaggeration to refer to South Africa as more of a secular than a religious society. As seen by the definition of "secularism" below, this would refer strictly to a non-religious society. Realistically and practically, it would be misplaced to describe South Africa as non-religious.

The fact is that our current society evidences both a variety of religious faiths and effectively leaves the choice of a particular religion, or even choosing not to be religious, up to every individual. More significantly, government does not play an official role in the affairs of religion. There is no official or formal policy in terms of which religion is enforced on the citizens

President of the Law Society of the Cape of Good Hope 2002 (2) SA 794 (CC) par 97; Dlamini $v$ Green Four Security 200611 BLLR 1074 (LC) par 16.

9 See MEC for Education: Kwazulu Natal v Pillay 2008 (1) SA 474 (CC) par 47.

10 See Prince $v$ President of the Law Society of the Cape of Good Hope supra par 97.

See Christian Education SA v Minister of Education supra par 33.

2 See MEC for Education: KZN v Pillay supra par 47.

13 According to the 2015 Household Survey Report, religious affiliations per province are grouped under what appears to be a finite nomenclature, namely Christian; Muslim; Ancestral tribal, Animist or other African traditional religions (ATR); Hindu; Jewish; Other religion; Nothing in particular; and Do not know (Stats SA General Household Survey 2015 www.statssa.gov.za/publications/P0318/P03182015.pdf (accessed 2015-07-22) 30). But this table must be read in the context that each recognised religion has the potential to embrace other forms and types of religions. "Other traditional African religions" can constitute any number or sum of religions or affiliations. For the same reason the Hindu faith can include mainline Buddhism but does not necessarily exclude Sikhism and Jainism as part of Hinduism. Alternatively, to what extent should or could Confucianism or Taoism also be considered a religion under the umbrella term of "Other religion"? For further reading see Marshall "Conceptual Issues in Contemporary Religious Freedom Research" 2013 International Journal for Religious Freedom $78-10$. Where reference to ATR is concerned, the term is used loosely to refer to the wide variety of religious practices in Africa which range from more formal recognised religions such as Catholicism and Protestantism to the well-known Zion Church with its headquarters at Zion City of Moria, east of Polokwane, to more traditional forms of worship of a ceremonial nature extending into deeply held cultural beliefs and traditions. For further reading on ATR see Van der Vyver "Law, Religion and Human Rights in Africa: An Introduction" 2008 African Human Rights Law Journal 337342 343; Hackett "Tradition, African, Religious, Freedom?" in Sullivan, Hurd, Mahmood and Danchin (eds) Politics of Religious Freedom (2015) 92-95; Mndende "Law and Religion in South Africa: An African Traditional Perspective" 2013 Dutch Reformed Theological Journal 74 82-83; Chimuka "Afro-pentecostalism and Contested Holiness in Southern Africa" 2016 Studie Historiae Ecclesiasticae 124 129-133. 
of South Africa. ${ }^{14}$ This state of neutrality on the part of government is underscored by the National Policy on Religion and Education ${ }^{15}$ which expressly provides as follows:

"Under the constitutional guarantee of freedom of religion, the state, neither advancing nor inhibiting religion, must assume a position of fairness, informed by parity of esteem for all religions, and worldviews. This positive impartiality carries a profound appreciation of spirituality and religion in its manifestations, as reflected by deference to God in the preamble to our Constitution, but does not impose these."

A similarity in such a state of neutrality can be drawn with the United States (US). As far as protecting the right to freedom of religion, the US depends on what is known as the "establishment clause" which provides that under the US Constitution "Congress shall make no law respecting an establishment of religion, or prohibiting the free exercise thereof". ${ }^{17}$ In Everson v Board of Education, ${ }^{18}$ Justice Black stated the following:

"Neither a state nor the Federal Government can set up a church. Neither can pass laws which aid one religion, or prefer one religion over another ..."

Effectively, what emerges from this model is a situation in which there is no involvement between the state or government and any religious affiliation and/or the practice thereof. Rawls advocates that this form of government is to be encouraged since the state refuses to use any particular form of religious ideology, which it imposes on its citizens. ${ }^{19}$ Religion and the freedom to practise one's beliefs are a matter left to the conscience and personal, subjective belief of each and every person - it is not a realm into which the government intends venturing. This has attracted some criticism on the grounds that it is not sufficient for a government to simply distance itself from notions of religious freedom as is demonstrated by the "establishment clause". The reasoning behind the criticism is that the government should not be so passive in relation to issues impacting on liberal democracies.

14 See Leatt "Faithfully Secular: Secularism and South African Political Life 1" 2007 Journal for the Study of Religion 29; Ismail "South Africa's Sunday Law: Finding a Compromise" 2001 Indiana Int and Comp LR 2001 563-586; Cook "God Talk in a Secular World" 2013 Yale Journal of Law and Humanities 435 437; Ferrari "Religion and the Development of Civil Society" 2011 Int Journal for Religious Freedom 29 35. Also see S v Lawrence, S v Negal; $S v$ Solberg supra in which the Constitutional Court had to consider the validity of the Liquor Act 27 of 1989 under the interim Constitution 200 of 1993 and in which the appellants had alleged (unsuccessfully though) that the prohibition against selling liquor on Sundays was inconsistent with their right to religious freedom in a secular society.

15 Available www.gov.za/sites/www.gov.za/files/religion_0.pdf. Hereinafter "the Policy".

16 Policy 5. Author's own emphasis added. As pointed out in the Policy 7, the South African Schools Act 94 of 1996 endorses the constitutional rights of all citizens to freedom of conscience, religion, thought, belief and opinion, as well as freedom from unfair discrimination on any grounds whatsoever, including religion, in public education institutions.

17 First Amendment.

18330 US 1 (1947) 15.

19 See Rawls Political Liberalism (1993) 29-33. 
However, when government has become more proactive in legislating laws, for example, those which call for the banning of religious symbols in forcing women of the Muslim faith to remove the hijab, niqab or burqa for air travel or for drivers' licence purposes, which laws are upheld and enforced through the judiciary, ${ }^{20}$ its conduct has not escaped scrutiny and will no doubt be the matter of ongoing criticism and debate. ${ }^{21}$ In whichever way one refers to the "establishment clause" as separating religion from state or the private affairs of citizens, this will not detract from the reality that in form and substance the state, even in what may conceivably be considered to be the most liberal of democracies, has an overriding interest in the name of public policy to limit basic and fundamental religious freedoms. ${ }^{22}$

The term "secularism" is derived from Latin saecularum ${ }^{23}$ meaning "from time to time" or "for all eternity". ${ }^{24}$ It has, however, come to be associated with being non-religious. ${ }^{25}$ It is important that it be understood in the context of a society which is not regulated as a theocracy ${ }^{26}$ but one in which allowance is made for the pursuit of individual and collective freedoms subject to the rule of law. ${ }^{27}$ Iran, Syria, Afghanistan and the Sudan, for example, can be regarded as theocratic states, where Islam is adopted not only as the official religion but also as the absolute rule of God as the law. This type of system is criticised by virtue of its totalitarianism and dictatorship. $^{28}$ The nexus between these regimes and religious

20 In Muhammad v Paruk 553 F. Supp.2d.893. (E.D. Mich.2008) a Muslim woman's claim against a car rental company who insisted she remove her veil was dismissed. The decision was upheld by the Supreme Court.

21 See Halmai "Religion and Constitutionalism" (undated) www.eui.eu/Documents/ DepartmentsCentres/Law/Professors/Halmai/Models-of-State-Church-Relations-and-Religi ous-Rights.pdf (accessed 2016-07-16) 11-12.

22 See the report by Kader Asmal, Minister of Education on the National Policy on Religion and Education (GG 25459 of 2003-09-12) 3-5 in which reference is made to various models of secularity in modern democracies. For example, a repressionist model aims to suppress religion; a separationist model seeks impartiality towards religions and worldviews and a "complete divorce of the religious from the public realm". Examples are given in respect of France and the US, but the practicality of giving effect to such a model based on the reality of public life is conceded. In addition there is the cooperative (what I would submit can be viewed as the embracive) model which seeks constructive dialogue between all interest groups and where there is awareness of the need to heed against coercion from the state. Cassell's New Latin-English / English-Latin Dictionary (1977) s v saecularum.

24 See Benson "Seeing through the Secular Illusion" 2013 Dutch Reformed Theological Journal 12 16-17.

25 See Benson "The Case for Religious Inclusivism and the Judicial Recognition of Religious Associational Rights: A Response to Lenta" 2008 Constitutional Court Review 295298 299; Farrow Recognising Religion in a Secular Society: Essays in Pluralism, Religion, and Public Policy (2004) 83-93; Benson "Notes towards (Re)Defining of the Secular" 1999 Univ of British Columbia LR 520 520-521.

26 In terms of imposing religious law like Sharia, which is used, interchangeably with Islamic law. See Oraegbunam "A Jurisprudential Review of the Controversies on the Nature of Islamic Law" 2011 American Journal of Comparative Law 95 99-102; Hursch "The Role of Culture in the Creation of Islamic Law" 2009 Indiana LJ 1401 1402-1407; Bradford "Bad Moon Rising: The Sharia Law Bans" 2013 Louisiana LR 600 601-604.

27 For further reading see Campos "Secular Fundamentalism" 1994 Columbia LR 1814 1825; Lenta "Religious Liberty and Cultural Accommodation" 2005 SALJ 352 363-366.

28 See Travis "Freedom of Theocracy?: Constitutionalism in Afghanistan and Iraq" 2005 Northwestern Journal of Int Human Rights 1 10-14; Backer "The Crises of Secular 
fundamentalism with the extant problem of ISIS, terrorism and currently the ongoing problem of the conflict in Aleppo stem from trenchant religiouslyheld views that express hostility in respect of any non-fundamentalist religion. ${ }^{29}$ Irrespective of the "secularism" label pinned to a particular society, ultimately what matters more is the extent to which citizens are at liberty to practise freely their religious beliefs without fear of reprisal. The practice of such belief, however bizarre, would be limited to not permitting such practices to extend to anything that would be harmful in that it is injurious to another person or living being, alternatively adversely impacts upon their human dignity. ${ }^{30}$

South Africa's description as a "rainbow nation" ${ }^{31}$ must be considered against the backdrop of its diverse cultural, ethnic and racial make-up. This diversity brings with it an array of divergent views, ideologies and opinions in respect of various subject matters, especially in relation to religion. However, we are reminded that it is this very diversity that actually unites us as a country. ${ }^{32}$ We are also reminded that central to tempering this diversity is exercising tolerance. ${ }^{33}$

Contextualising secularism in South Africa appears from the following dictum by Sachs $\mathrm{J}$ in Minister of Home Affairs v Fourie: ${ }^{34}$

Liberalism and the Constitutional State in Comparative Perspective: Religion, Rule of Law, and Democratic Organization of Religion Privileging States" 2015 Cornell Int LJ 51 60-61; Ahmed and Ginsburg "Constitutional Islamization and Human Rights: The Surprising Origin and Spread of Islamic Supremacy in Constitutions" (University of Chicago Public Law and Legal Theory Working Paper No. 477) 2014 12-15.

29 Such as Christianity or Judaism or any other religion that is not consistent with radical Islam. For further reading see Mahalingham "Women's Rights and the 'War on Terror': Why the United States Should View the Ratification of CEDAW as an Important Step in the Conflict with Militant Islamic Fundamentalism" 2004 California Western Int LJ 171 172-178; Rauch "Fundamentalism and Terror" 2015 Journal of Terrorism Research 28 29-31; Chang "Islamic Fundamentalism, Jihad, and Terrorism" 2005 Journal of Int Development and Cooperation 57 58-63.

30 Take for example the recent South African case of the church pastor who sprayed the insecticide Doom on congregants claiming that by doing so he could heal them. It is a matter of concern that whilst acknowledging that the spray contained harmful substances, the Commission for the Promotion and Protection of Cultural, Religious and Linguistic Rights stated that on account of the fact that the congregants were consenting adults there was little that could be done until a regulatory body is established for churches in South Africa. The Human Rights Commission of South Africa, it is submitted, would have had the necessary authority and jurisdiction to address and investigate the matter. See Masuabi "Doom Pastor's Congregants Urged to Seek Medical Care if They Were Sprayed" Eyewitness News (2016-11-23) http://ewn.co.za/2016/11/23/doom-pastor-limpopo-healthdepart-advises-congregants-to-seek-medical-care (accessed 2016-12-16).

31 A term coined by Archbishop Desmond Tutu during South Africa's transition to a democratic dispensation. See Buqa "Storying Ubuntu as a Rainbow Nation" 2015 Verbum et Ecclesia 1-8; Herman "Jacob Zuma and Minority Groups in Post-Apartheid South Africa: An Examination of his Reconciliation Policy toward the Afrikaners" 2011 AJPSIR 10-20.

32 See the wording of the Preamble to the Constitution that states that "South Africa belongs to all who live in it, united in our diversity".

33 Sachs "The Sacred and the Secular: South Africa's Constitutional Court Rules on SameSex Marriages" 2013-2014 Kentucky LJ 147 158; Clark and Corcoran "Pluralism, Secularism, and Tolerance" 2000 Rhetoric and Public Affairs 627; Morini "Secularism and Freedom of Religion: the Approach of the European Court of Human Rights" 2010 Israel LR 611.

342006 (1) SA 524 (CC). 
"In the open and democratic society contemplated by the Constitution there must be mutually respectful co-existence between the secular and the sacred. The function of the Court is to recognise the sphere which each inhabits, not to force the one into the sphere of the other ... The hallmark of an open and democratic society is its capacity to accommodate and manage difference of intensely-held world views and lifestyles in a reasonable and fair manner ... The objective of the Constitution is to allow different concepts about the nature of human existence to inhabit the same public realm, and to do so in a manner that is not mutually destructive and that at the same time enables government to function in a way that shows equal concern and respect for all ,.."

The ever-present spectre of modern-day terror attacks and ongoing potential attacks on the lives of innocent people by religious fundamentalists underscores the heightened relevance of religion in secular and non-secular societies. Such terror attacks, whilst capable of being construed and interpreted through the prism of various political ideologies and views, is premised on the fundamental notion of intolerance. This is the most extreme manifestation of intolerance in that it speaks of deliberate and premeditated conduct on the part of one believer to wage a holy war (jihad) against nonbelievers.

An unyielding fervent belief in something to the express exclusion of any other view, irrespective of its persuasiveness, may be defined as evidencing a strong conviction. However, it can also be defined as intolerant where the other view is summarily dismissed merely because it is different and for reasons pertaining to rationality or grounds that are justified. To the extent that a believer holds such views with reference to his or her own religious convictions and does not express them in a manner that poses harm to any person or living being, it cannot be deemed objectionable. However, evident problems arise when the expression of such views infringes on the basic human rights, such as human dignity and or the right to life, of another person.

This collision of individual interests can take place in the public realm, for example, where women are forced to clothe their bodies in a certain manner, for example, the enforcement of women having to wear the hijab in a theocracy. Some individual females may feel that the enforcement of such a dress code infringes their individual freedom of choice. On the other hand, the banning of women wearing face coverings ${ }^{36}$ in public in France and Brussels since 2010 and 2011 respectively has been met with criticism that it is an undue limitation on their right to religious freedom. ${ }^{37}$ The above

35 Par 94-98. For a discussion on accommodating a diversity of intensely-held world views and lifestyles, particularly majoritarian as opposed to minority or less popular views, see City of Tshwane Metropolitan Municipality v Afriforum 20169 BCLR 1133 (CC) par 8, 14 and 164.

36 Commonly referred to as the burqa or niqab.

37 See Pei "Unveiling Inequality: Burqa Bans and Nondiscrimination Jurisprudence at the European Court of Human Rights" 2013 Yale LJ 1089-1092; Helbling "Opposing Muslims and the Muslim Headscarf in Western Europe" 2014 European Sociological Review 243 248; Nougayrède "The Lessons of Brussels: Jihadi Terrorism Crosses Borders, and So Must Solutions" 1 April 2016 The Guardian. 
instances are in some or other way all demonstrative of a lack of tolerance to permit others to express their religious freedom in a particular manner.

\section{Forbearance of differences}

The word "tolerance" is derived from the Latin verb tolerare. ${ }^{38}$ It is understood as having to "put up with" or "endure" something. ${ }^{39}$ Clark and Corcoran argue for a notion of "thick tolerance" in a pluralistic secular society. Put differently, in a society in which representations of various cultures and beliefs are manifest, allowance must be made for the fact that persons who hold religious beliefs are accepted as part of what constitutes that society. These beliefs - even if held by only a minority - must be protected. To do otherwise would constitute unfair religious discrimination. ${ }^{40}$ A formal legal rationale for this is premised on the fact that in terms of the UN Declaration on the Rights of Persons Belonging to National or Ethnic, Religious and Linguistic Minorities, ${ }^{41}$ provision is made for the fact that state parties to the Declaration "shall protect the existence and the national or ethnic, cultural, religious and linguistic identity of minorities". ${ }^{2}$

The Declaration clearly gives impetus to the Constitution's express provision for a Commission for the Promotion and Protection of the Rights of Cultural, Religious and Linguistic Communities. ${ }^{43}$ The promotion and protection of religious communities in general and minorities in particular are necessary for the overarching protection and advancement of human rights equality jurisprudence that seeks not only to address and eliminate typical prima facie discrimination such as blatant racism but also unfair discrimination, even against minority groups, and any form thereof, including disparate (otherwise known as adverse or indirect discrimination), which is objectionable on account of the fact that it degrades another individual or group of individuals and thereby impairs their human dignity. ${ }^{44}$

An additional rationale for making allowance for different or minority views is a so-called non-legal premise. This is based on the fact that in many instances someone may be committed to their own religious belief ${ }^{45}$ whilst simultaneously respecting the beliefs of others. It is in this sense that tolerance expressed as a notion of "forbearance" ${ }^{\text {"6 }}$ appears to be apposite.

\footnotetext{
See Cassell's New Latin-English / English-Latin Dictionary (1977) s v tolerare.

Clark and Corcoran 2000 Rhetoric and Public Affairs 629.

See Clark and Corcoran 2000 Rhetoric and Public Affairs 628.

41 Hereinafter "the Declaration". Adopted by the General Assembly Resolution 47/135 of 18 December 1992. See Hill "Freedom of Belief for Minorities in States with a Dominant Religion: Anomaly and Pragmatism" 2014 African Human Rights Law Journal 266 273-274 Roach "Minority Rights and an Emergent International Right to Autonomy: A Historical and Normative Perspective" 2004 Int Journal on Minority and Group Rights 411 412-417.

42 Article 1. See Hill 2014 African Human Rights Law Journal 273-274.

43 Established under s 185-186 of the Constitution as a Chapter 9 State Institution Supporting Constitutional Democracy as in terms of $s 181$ of the Constitution.

44 See Van der Vyver "The Right to Self-Determination of Cultural, Religious and Linguistic Communities in South Africa" 2011 PER 119.

45 Which can be non-religious, such as atheistic or agnostic.

46 McConnell “Why Protect Religious Freedom?" 2013 Yale LJ 530536.
} 
Benefits arising from tolerance are evidenced as a confirmation of our sense of humanity, community, society and commitment to change. ${ }^{47}$ Increased disadvantages associated with ideas or conduct, on the other hand, are likely to deter rather than attract enthusiasm on the part of an individual. Accordingly, it should be important for tolerance not to be considered in isolation but to be contextualised in terms of benefits outweighing the disadvantages arising from the forbearance or tolerance. ${ }^{48}$ Many would agree that the anxiety, negativity and overall sense of hostility associated with harbouring a spirit of intolerance do not constitute a healthy and positive human experience. On the other hand, tolerance is not absolute. Conduct or expression of a belief that impacts negatively on another person's human dignity or causes harm to another cannot and should not be tolerated. ${ }^{49}$

Our multicultural and pluralistic society of South Africa, whilst vibrant in divergent views and differences - which may be seen by many as the essence of our strength - can also serve as an Achilles heel. The Penny Sparrow saga proved to be a catalyst for ongoing racial and hate speech tensions - a hitherto hidden scourge which many thought had been buried with the apartheid regime. This has culminated in the drafting of the Prevention and Combating of Hate Crimes and Hate Speech Bill. ${ }^{50}$ The enactment of the Bill will have far-reaching implications in terms of freedom of expression ${ }^{51}$ equality; ${ }^{52}$ human dignity; ${ }^{53}$ and freedom of religion, belief and opinion. ${ }^{54}$ This fact may very well be indicative of the paradoxical and complex make-up of South African society; or indeed of any pluralistic, multicultural society where the inevitable situation is that minority views and beliefs will clash with majority views, whether they are religious or otherwise in nature. Accordingly, the need for tolerance becomes imperative. It serves, in a sense, as a means to counterweigh tensions that would otherwise make living conditions unbearable. ${ }^{55}$

47 For further reading see Hoexter and Olivier The Judiciary in South Africa (2014) 78-81, especially the authorities cited at fns 77 and 78; Klare "Legal Culture and Transformative Constitutionalism" 1998 SAJHR 146 150; Pieterse 2005 "What Do We Mean when We Talk about Transformative Constitutionalism?" SA Public Law 155 161; Ngcobo "South Africa's Transformative Constitution: towards an Appropriate Doctrine of Separation of Powers" 2011 Stell LR 37; De Vos "A Bridge Too Far? History as Context in the Interpretation of the South African Constitution" 2001 SAJHR 19.

48 Menski "Fuzzy Law and the Boundaries of Secularism" 2010 PER 30 41-42; Preece "Multiculturalism, Dignity and the Liberal State in Canada" 1998 Politica 149 150; Du Plessis "Apartheid, Religious Pluralism, and the Evolution of the Right to Religious Freedom in South Africa" 2016 Journal of Religious History 237 241-243.

49 Becker and Parker "Moving towards Understanding One Another: Cornelia Roux on Religion, Culture and Human Rights" 2014 Journal for the Study of Religion 234 261-262; Jackson "Religion Education, Intercultural Education and Human Rights: A Contribution for Cornelia Roux" 2014 Journal for the Study of Religion 714

50 In terms of GG 40367 (2016-10-24). Hereinafter "the Bill".

$51 \mathrm{~S} 16$ of the Constitution.

$52 \mathrm{~S} 9$ of the Constitution.

53 10 of the Constitution.

$54 \mathrm{~S} 15$ of the Constitution.

55 See Du Plessis 2016 Journal of Religious History 238-242; Maussen and Vermeulen "Liberal Equality and Toleration for Conservative Religious Minorities. Decreasing Opportunities for Religious Schools in the Netherlands?" 2015 Comparative Education 87 
Whether we conceive of putting up with beliefs that are different in terms of notional "thick tolerance" or simply "forbearance", it confirms the fact that there is a constant need for different people to deal with different beliefs. For some, this is innocuous; for others, this can serve as a crucible. When different religious beliefs are regarded in an objectionable light, ${ }^{56}$ they can otherwise be referred to as "Other beliefs". This notion of the Other galvanises views of differences, separatism, lack of coherence or unity between communities. It serves as fertile ground for hostility, or confronting and stereotyping, all of which are in some way or other associated with religious unfair discrimination. ${ }^{57}$ Hypothetically, even when individuals share religious beliefs which are materially homogenous, the likelihood of differences arising regarding certain aspects or even practices in accordance with such belief may differ - a fortiori in a multicultural pluralistic and secular society. As such, the need to temper differences by means of tolerance is an essential requisite facilitating dialogue and accommodation of majority ${ }^{58}$ and minority religious beliefs. This is especially useful, and in fact necessary, in societies where religious freedom is manifested in what may appear to be societies with increasing secular values and ideologies. ${ }^{59}$

Tolerance has a relevant role to play as a means by which differences regarding religious beliefs in a multicultural and secular society can be addressed. Intrinsically, it must be conceived of as a notion, which enables individuals or communities ${ }^{60}$ to live together despite different religious or secular beliefs. ${ }^{61}$ Used optimally, it can diffuse tension, thereby preventing

88-94; Minow "Religious Exemptions, Stating Culture: Foreword to Religious Accommodation in the Age of Civil Rights" 2015 Southern California LR 453 459-460; Bacrac "The Importance of Dialogue and Tolerance in a Plural Society" 2015 European Journal of Social Sciences Education and Research 26 27-30.

56 On whatever basis.

57 See Leigh and Hambler "Religious Symbols, Conscience, and the Rights of Others" 2014 Oxford Journal of Law and Religion 2 19-20; Bernard "Reasonable Accommodation in the Workplace: To Be or not to Be?" 2014 PER 2869 2883-2888; Walsh "The Right to Equality and the Employment Decisions of Religious Schools" 2014 University of Notre Dame Australia LR 107 123-131.

58 The rationale underlying the reference to majority religious beliefs is that recently a trend has developed in terms of which members of the Islam faith have been victim to stereotyping allegations of terrorism simply due to actions on the part of the fundamentalist movement ISIS. See Sides and Gross "Stereotypes of Muslims and Support for the War on Terror" 2013 Journal of Politics 583-598; Richardson "Obama warns: Discrimination against Muslims helps ISIS" 12 December 2015 The Hill http://thehill.com/blogs/blog-briefing$\mathrm{room} /$ news/263017-obama-warns-discrimination-against-muslims-helps-isis (accessed 2015-12-19); Simkins and Kelly "Religion and Identity" 2016 Journal of Religion and Society 113 114-116; Van der Vyver "Religious Fundamentalism and Human Rights" 1996 Journal of Int Affairs 21 22-26; Madalla and Abdulfattah "Theories of Prejudices and Attitudes toward Muslims in the United States" 2012 Int Journal of Humanities and Social Science 21 24-26.

59 Clark and Corcoran 2000 Rhetoric and Public Affairs 633; Ferrari 2011 Int Journal for Religious Freedom 29 32-34; Grim, Clark and Snyder "Is Religious Freedom Good for Business: A Conceptual and Empirical Analysis" 2014 Interdisciplinary Journal of Research on Religion 16.

60 Which is used in the loose sense of the word to include, but not be limited to, organisations and juristic persons.

61 Or even atheistic or agnostic. See Kettell "Faithless: The Politics of New Atheism" 2013 Secularism and Non-Religion Journal 61 62-65; Clemens and Gries '"Religious Nones' in 
and eliminating religious unfair discrimination. ${ }^{62}$ Fundamental to the concept of tolerance is a sense of having to endure, put up with and forbear. Notionally and conceptually, these latter terms fail, however, to resonate with a positive and vibrant authentic sense of a reconciliation of differences. Instead, they tend to align themselves with thoughts of something that is transient and associated more with an element of coercion or notional inducement on the part of anyone who has to forbear another. For reasons that are articulated below, it is contended that tolerance - as a concept however, fails to fully embrace what we should be striving to attain under the South African democratic dispensation and that it would be more appropriate to substitute tolerance with a celebration of differences.

\section{Curtailing religious freedoms: expressions of tolerance}

As previously stated, none of the rights enshrined in the Bill of Rights are absolute. In the case of religious freedom, the extent to which its expression may be manifestly limited in public is the subject matter of ongoing international debate. In 2010 France was the first country in the European Union making it illegal for women to wear either the niqab or burqa anywhere in public. ${ }^{63}$ The banning of the burqa and niqab worn by females in public continues to be a contentious matter regarding a limitation on religious freedom.

the United Kingdom: How Atheists and Agnostics Think about Religion and Politics" 2016 Politics and Religion Journal 1 2-10.

62 See Kumar "Resistance and Change - Religion in the Middle: Assessing the Role of Religion in Social Transformation in South Africa" 2013 Journal of Natal and Zulu History 1 33; Grim "Religion, Law and Social Conflict in the 21st Century: Findings from Sociological Research" 2012 Oxford Journal of Law and Religion 249-271; Benson "South African Charter of Religious Rights and Freedoms: Constitutional Framework, Formation and Challenges" 2011 Int Journal for Religious Freedom 125 127; Du Toit and Potgieter Unfair Discrimination in the Workplace (2014) 1. See also the Reuters report which states that "[v]iolence and discrimination against religious groups by governments and rival faiths have reached new highs in all regions of the world ..." (Heneghan "Religious Groups Face Increased Hostility Worldwide - Report" 14 January 2014 Reuters World News http://uk.reuters.com/article/uk-religion-hostility-report-idUKBREA0D0XK20140114

(accessed 2015-01-28); United States Department of State Bureau of Democracy, Human Rights and Labor International Religious Freedom Report for 2013 https://www.state.gov/documents/organization/222225.pdf 10 (accessed 2015-01-29); European Union Agency for Fundamental Rights Fundamental Rights: Challenges and Achievements in 2013 - Annual Report 2013 (2014) http://fra.europa.eu/sites/default/ files/ fra-2014-annual-report-2013-2_en.pdf (accessed 2015-01-29) 129; Nel "When Can the Persecution of Christians Be Considered as Genocide or a Crime against Humanity?" 2013 Int Journal for Religious Freedom 173175.

63 This was pursuant to the French Constitutional Council finding on 7 October 2010 that a bill making it illegal to wear the Islamic burqa or niqab or any other face veil in public conformed with the Constitution. See Parmar "Bans on the Full Face Veil and Human Rights: A Freedom of Expression Perspective" 2010 Article $19 \mathrm{https}: / / w w w . a r t i c l e 19 . o r g / d a t a / f i l e s /$ pdfs/publications/bans-on-the-full-face-veil-and-human-rights.pdf (accessed 2016-2-24) 7 esp fn 12.

64 See Barker "Rebutting the Ban the Burqa Rhetoric: A Critical Analysis of the Arguments for a Ban on the Islamic Face Veil in Australia" 2016 Adelaide LR 191 192-196; Laborde "State Paternalism and Religious Dress Code" 2012 Int Journal of Constitutional Law 398 399_ 
Restrictions on the manifestation of religious beliefs in the workplace may also take place due to varying reasons. These could range from the inherent requirements of the job (IROJ) ${ }^{65}$ to an alleged inability on the part of the employer to accommodate the employee's manifest religious beliefs on account of it imposing undue hardship upon the employer. ${ }^{66}$ Moreover, an employer may even defend him- or herself against an allegation of religious unfair discrimination by proving ${ }^{67}$ that the discrimination was rational, not unfair, or otherwise justifiable. ${ }^{6}$

Such limitations on the expression of religious freedoms, whether in the public or employment realm, may be seen as a consequence of balancing competing fundamental rights. On the one hand, there is the right to freedom of religion that is sought to be expressed in a particular manner. This may be pitted against a secular right or interest, such as public safety, for example by requiring that a full-face photograph be taken for a driver's licence or passport photograph (hereinafter referred to as the "public interest") ${ }^{69}$ or the IROJ imposed by an employer (hereinafter referred to as the "workplace case"). Whatever our emotive responses may be to the balancing of these competing rights, ultimately ${ }^{70}$ they are assessed with reference to principles of rationality, reasonableness and proportionality. ${ }^{71}$ In the public interest, the religious freedom is outweighed by concerns for the general safety and security of the public. In the workplace case, it is the interests of the employer, in relation to the IROJ, which outweigh the individual expression of freedom of religion. However, in both instances, the curtailing of religious freedom is a notional form of toleration. The freedom of the individual to express or manifest his or her religious belief is "put up with" or "borne" only

404; Kutoroff "First Amendment versus Laïcité: Religious Exemptions, Religious Freedom, and Public Neutrality" 2015 Cornell Int LJ 247 256-260.

65 In terms of s 192(2) as read with s 187(2)(a) of the Labour Relations Act (LRA) 66 of 1995 or s 6(2)(b) of the Employment Equity Act (EEA) 55 of 1998.

66 Dlamini $v$ Green Four Security supra par 32, 52 and 69. Although no statutory definition exists in the LRA defining "reasonable accommodation", the term as a ground upon which the employer is required to prove that discrimination is fair by showing what steps have been taken to reasonably accommodate diversity appears in $s$ 14(3)(i) and (ii) of the Promotion of Equality and Protection of Unfair Discrimination Act (PEPUDA) 4 of 2000. For further discussion of this term and the extent of its use, see Henrico "Mutual Accommodation of Religious Differences in the Workplace - A Jostling of Rights" 2012 Obiter 503.

67 On a balance of probabilities.

68 In terms of s 6(1), as read with s 6(11) of the EEA (as amended by the Employment Equity Amendment Act 47 of 2013).

69 See Deluisi "Laws in the United States and France Do Not Discriminate against Muslim Women" 2015 Law School Scholarship 1 17-18; Custos "Secularism in French Public Schools: Back to War? The French Statute of March 15, 2004" 2006 American Journal of Comparative Law 337 340-342.

70 In the absence of parties agreeing between themselves to a resolution of differences.

71 For further reading on the application of these principles on the adjudication of fundamental competing human rights, see Beatty The Ultimate Rule of Law (2004) 163; Kruger "The South African Constitutional Court and the Rule of Law: The Masethla Judgment, a Cause for Concern?" 2010 PER 467-484; Pieterse-Spies "The Role of Legislation in Promoting Equality: A South African Experience" 2013 TSAR 676; McGregor "Employees' Right to Freedom of Religion versus Employers' Commercial Interests: A Balancing Act in Favour of Diversity. A Decade of Cases" 2013 SA Merc LJ 223; Minister of Health v New Clicks South Africa (Pty) Ltd 2006 (2) SA 311 (CC) par 637. 
to the extent that it is permitted by the respective public interest or workplace case. This may be the result of the outcome of the balancing of competing fundamental rights. This manner of tolerance requires consideration in terms of the South African commitment to a specific constitutional order of a transformative constitutionalism. It is contended that what this type of order envisages is not mere toleration but actual celebration of religious freedoms. For reasons articulated later, the notion of celebration, as opposed to toleration, is essential. It is further contended that distinguishing between "toleration" and "celebration" is not a matter of mere semantics. Whilst the approach to the outcome of a balancing of competing fundamental rights may remain unaltered, it is imperative that our culture of justification, which is vital to transformative constitutionalism, extends to a culture of celebration of differences between individuals. A celebration of these differences may hold the promise of a consolidated sense of unity in the various religious freedoms individuals are entitled to express.

\section{CONCLUSION}

This article has looked at the complexities arising from expression of religious freedoms in a modern multicultural pluralistic society or workplace. The optimal balance of such competing interests may be in applying what is rational, reasonable, or proportionate with reference to the facts and circumstances of each and every dispute. However, an overarching consideration in our democratic dispensation must be the extent to which we are prepared to tolerate those who are different to ourselves. There is a problem with the concept of tolerance. Whether we conceive tolerance simply as "putting up with" or notionally a "thicker sense of tolerance" we are still left essentially with a concept of having merely to endure. If we are to speak of a society in which differences are accounted for and individuals are treated with respect irrespective of their religious beliefs, then tolerance is insufficient and inappropriate on account of the fact that it fails to resonate with a sense of true commitment to inclusivity. The need to merely tolerate must be revisited in terms of the necessity to rather celebrate the pluralistic differences in the South African "rainbow nation". 